Миливоје В. МЛАЂЕНОВИЋ Универзитет у Новом Саду Педагошки факултет у Сомбору
Оригинални научни рад

Примљен: 24. 10. 2016. Прихваћен: 10. 02. 2017.

\title{
ЕСЕЈИ ЈОВАНА ХРИСТИЋА О ДРАМИ И ПОЗОРИШТУ
}

\begin{abstract}
У раду се анализом стила Христићевих есеја о драми (Козачински, Стерија, Трифковић, Бојић, Симовић и др.) и позоришту утврђује однос према суштини драмских и позоришних категорија. Идентификују се ауторске интервенције, коментари, рефлексије које текстовима дају карактер есејистичког устројства. Посебна пажња биће усредсређена на хумор и иронију као особеност Христићеве позоришне критике (Позоришни реферати; Позориште, позориште), сатирично-ироничну „критику критике”, подсмех модерном критичарском „велеумљу”. У закључку се истиче да су стилске особине Христићеве поезије, драмских дела, позоришне и књижевне критике (равнотежа између певања и мишљења, идеје и осећања, склад, пропорционалност, разложност, ригорозност) једнако присутне и у есејима и да представљају неразложиву целину есејистичко-научног мишљења Јована Христића.
\end{abstract}

Кључне речи: Јован Христић, драма, позориште, есеј, критика, позоришна критика.

Сви истраживачи и аналитичари сагласни су да су драма ${ }^{1}$ и позориште главно подручје интересовања, а форма есеја и есејистички стил доминантан поступак у укупном делу Јована Христића. Есеји разматрани у овом раду захватају три подручја: опус драмских писаца, позориште као естетски феномен, те позоришну критику као најособенији вид есејистичке критике.

Есејистички карактер Христићевих текстова, као његову главну особеност и интенцију најједноставније је установити у текстовима које и он сам жанровски одређује као есеје, а „најнеухватљивија” је природа Христићевих текстова у збиркама позоришних критика. Његова ерудиција се заснивала:

[...] једним делом на писаној речи, на ономе што је Христић сазнавао читањем, а другим, можда још важнијим, на ономе што је сазнавао гледањем позоришних представа, учест-

\footnotetext{
${ }^{*}$ milivoje_mladjenovic@yahoo.com

${ }^{1}$ Саша Радојчић, судећи према неким Христићевим изјавама, закључује да је могуће да најистакнутије место у Христићевом „схватању човековог креативног односа према свету не припада ни филозофији ни поезији, већ - драми, јер драма, у лику трагедије, може, по Христићу, непосредније од филозофије и потпуније од поезије да обухвати узорну слику човека и његових односа" (2013: 38).
} 
вовањем у животу позоришта, посматрањем глумаца, јер за њега је драма постојала само кроз позориште и као таква могла се разумети и тумачити далеко боље кроз представу него у процесу читања (Фрајнд 2013: 33).

\section{Есеји о драмским писцима}

Јован Христић је неуморни неимар виртуелних позоришних представа у подручју драмског текста. То је, дакле, његов аутентични поступак у свим есејима о драмским писцима који Марта Фрајнд тачно дефинише као „уметност тумачења драме", алудирајући на капиталну хрестоматију Umetnost tumačenja poеzije у едицији коју је уређивао управо Јован Христић. Такво гледиште поткрепљује и став самог аутора: „Свако критичко тумачење једног драмског текста у ствари је, мање или више отворено, замишљање једне могуће представе, и ја замишљам једну представу" (Христић 2005: 228). Било да пише о светским, или драмским писцима из наше прошлости или савремености, Христић, на књижевно-критички начин „режира” анализирана драмска дела. Отуда је најпробитачније Христићевом деловању на подручју драме, позоришта и позоришне критике приступити интегративно, јер је реч, готово увек, о примени истоветног, есејистичког поступка, али у различитим књижевним облицима. Притом, ваља имати на уму да је Христић, како је примећено:

[...] елиотовац: традиција се не насљеђује; она се стиче креацијом и избором. Ерудиција претходи избору, а у избору је суштина модерног односа према традицији; у избору и у историјском осјећању [...]. Није довољно свашта знати; неопходно је изабрати из усвојенога и освојенога; учинити изабрано својим; ускладити га са својим сензибилитетом и историјским осјећањем (Делић $2013: 11$ ).

И Тонко Мароевић Христићеву есејистику одмерава према Елиотовој концепцији налазећи да га је такво упоређивање учинило „nezamjenjivim sugovornikom u pitanjima kriterija i valorizacije, piscem koji je umio povezati empiriju i teoriju, dijakroniju i trajni prezent” (Мароевић 2016). Ту Христићеву „спрегу знања и невиног погледа који се баца на конкретно драмско дело” (Селенић 1981), одликује још и „класицистички уздржана емоција” (Фрајнд 2013: 33), особина која је можда од кључног значаја за Христића писца есеја, јер укупно његово дело одише духом страсне преданости античком начину мишљења, говора и осећања.

Христићева је страсна тежња да осим анализе драмских писаца реконструише време у коме су они стварали.

Srbi su Traedokomediju videli kao svoju prvu istorijsku dramu. Ali šta ako drama Kozačinskog uopšte nije istorijska drama, već nešto sasvim drugo, pita se Hristić u eseju $O$ Traedokomediji Kozačinskog. I analizirajući 'dejstvo' po dejstvo, odnosno scenu po scenu, utvrđuje da je srpska istorija, Kozačinskom, strancu, poslužila kao sredstvo da se kaže ne samo panegirik Vikentiju Jovanoviću, nego da se stvori 'scenario', čvrsta dramska konstrukcija, kao osnova bogatog baroknog spektakla, potpuni teatar (Млађеновић 2006: 155).

Управо ти, до сада неуочени аспекти, јесу велика, иновативна вредност његових есеја. Као када у есеју „Sterijine komedije i njihova dramaturgija”, 
„'savetuje' da Sterijine komedije valja čitati od kraja! Tako bi se u njima ispod tanušnog sloja moralne pouke lakše uočila dubina smisla koji je trajniji i značajniji od izrečenog naravoučenija” (Млађеновић 2006: 155).

Христић такође уме да излучи, како бележи Мароевић, „из нафталина” „vodviljsku, laku sentimentalnu komiku Koste Trifkovića” (2016) и да јетко опомене како су звездани часови његових изванредних једночинки прошли упркос њиховој савршеној форми. Христићева горчина је с разлогом испољена, јер Трифковић би морао да има истакнуто место у историји српске драме, зато што, колико год сурово звучало, до појаве Нушића, по таленту и делима нема писца који има такав значај. Полазећи од већ давно утврђене оцене о Избирачици као једне од наших најбољих комедија, Христићев есеј се претапа у беспрекорну анализу водвиљске форме, истичући нарочито њену конструкцију „Без геометрије нема водвиља”, егзактан је Христић.

Есеј „Драме Милутина Бојића” је једна мала узбудљива студија у којем аутор открива је да је позорница један од кључних елемената за разумевање његових драма, јер су поезија и позориште у сталном преплитању. Театарске елементе налази у његовој поезији, а у његовим драмама обнову драмског стиха, и у том смислу пореди Бојића са Ростаном.

Блага полемична нота осећа се у есеју „О Дубровачкој трилогији Ива Војновића". Христић тврди да најтемељнији познавалац дела овог писца, Дарко Сувин, није у праву када ове драме из живота пропадајуће дубровачке властеле сврстава у „отворену драматургију”, јер су оне описане посве класично, у мелодрамском поджанру. У те три лирске а драматске слике (Allons enfants, Сутон, На тараци) Христић, сходно свом критичком ставу, гради једну „замишљену представу”, посматра Војновићеве ликове у односу на њихову класну припадност - служавке, пучане, бонвиване, властелу.

Два света - свет позоришта и свет свакодневне стварности сударају се у драми Путујуће позориште Шопаловић Љубомира Симовића. Христић, исконски заинтересован за питања драме и позоришта, у овом је есеју у потрази за оним тренутком када се драмском писцу Симовићу придружио песник Симовић. Христић нуди слојевиту класификацију суочавања и преплитања живота у овој драми: одрицање од позоришта под притиском стварности (Василије Шопаловић и Јелисавета Протић); преображавање стварности под притиском уметности (Софија Суботић и батинаш Дробац); те појаву да уметност најдубље преображава живот, али и да уметност такође бива преображена (Филип Трнавац). Путујуће позориште Шопаловић није само драма о односу уметности и живота него и драма о спаситељу, развијена од реалистичке опипљивости до песничке слике, у чијем ритму „не можемо а да не осетимо дисање стиха, тензију која се природно сажме и згусне у стих" (Христић 2005: 238).

У свим есејима о драмским писцима Христић образлаже унутрашњу логику дела и, будући да је ,један од наших свезнадара који је своје знање умио да контролише и да из њега бира" (Делић 2013: 11), укључује у истом тренутку неколико дисциплина: теорију књижевности, књижевност као стваралаштво, филозофију, драматургију и театрологију. Одиста особена књижев- 
на форма: нити су „чисти” есеји, нити само „есејистичка критика”. Њихов есејистички карактер је непобитан јер никад не искључује најистакнутију црту есеја: субјективно-вредносни став. Прелаз из есеја у критику и критике у есеј, граница између есеја и књижевне критике код Христића не постоји.

\section{Есеји о позоришту}

Без обзира на перманентну испреплетаност (већ смо установили да су подручја интересовања код Христића једва разлучива), есеји у којима се тематизују и проблематизују питања из подручја драматургије, структуралних начела и естетичких питања позоришне историје и савремености, позоришне семиологије и рецепције, за разлику од есеја о драмским писцима, углавном су настали конкретним поводом. Полазиште им је, најчешће, приказ нове књиге из области театрологије, позоришни или општекултурни догађај, истакнута личност из позоришне историје или савремености. ${ }^{2}$ Управо онако како је говорио и Ђерђ Лукач у писму „О суштини и облику есеја”, а на што нас Христић аутопоетички подсећа у есеју „О јединству у делу Исидоре Секулић” наглашавајући да је та пригодност „поруџбине” једино што би се могло приговорити Исидори Секулић која је „била плодан есејиста који није бежао ни од једне сврхе и ни од једне прилике ако је желео нешто да каже и ако му се чинило да је имао шта да каже” (Христић 2005: 119). ${ }^{3}$

Мора да је и есеј „Београдско драмско позориште и његове златне године" настао неком јубиларном пригодом, не би било тешко то ни проверити, али није суштина у годишњици него у томе како је овај есеј интониран. У њему сећање, као главна компонента меланхолије, а без које тешко да се истка вредан есеј, има такорећи ефекат рефрена у прозној творевини („Сви смо одрасли у Београдском драмском позоришту...”). Причу о златном добу Београдског драмског позоришта Христић оставља историчарима позоришта („,ово није историја већ су сећања”, упозориће нас више пута), а он описује сензибилитет позоришта које је „razgovaralo sa nama i mi smo razgovarali s njim” (Христић 2002: 50), нагласивши да „,samo u jednom periodu svoga života pozorište može da bude nešto više od pozorišta" (Исто: 51).

Два уводна пасуса у есеју „Теоријска питања, практични одговори” развијеном из приказа књиге словеначког театролога Андреја Инкрета Предмет и принщип драматургије (1987), врве од питања о односу позоришне пред-

\footnotetext{
${ }^{2}$ Наводећи разлоге који су могли да определе Христића да изабере есеј као адекватан облик изражавања, Саша Радојчић наводи и „неке личне вредносне преференције, али можда највише осећање да оном најважнијем, оном стваралачком језгру, треба приступати што разноврснијим средствима како би се уобличило и изразило што потпуније и што нијансираније" (Радојчић 2013: 39).

${ }^{3}$ Овај приговор побуђује, међутим, питање унутрашњег јединства есеја уопште, а не само есеја Исидоре Секулић. Одговором да нам не преостаје ништа друго „до да јединство у делу Исидоре Секулић тражимо у јединству једног високо културног посредништва и просветитељства” (Христић 2005: 120), аутор предочава и властити поглед о суштини облика есеја; „нацртао” је сопствени модел есеја.
} 
ставе и драмског текста, о дослуху редитеља и драмског писца. Тако Христић претвара овај есеј у динамичну, дијалошку расправу о редитељском читању ослоњеном на Ан Иберсфелд, Романа Ингардена и друге теоретичаре, покушај ,da se misli zajedno sa piscem, da se jedan tekst ponovo stvori zajedno sa piscem" (Христић 2002: 67). Подсећања и сећања позоришног критичара на конкретне представе додатно појачавају ефектност есејистичког облика.

Из кратког, језгровитог есеја „Какве смо дивне редитеље имали” иницираног књигом Парадокс о редитељу читалац дознаје да Бору Драшковића занима „позоришна режија као судбина” (Христић 2002: 70), и бележећи тренутке из „радионица” великих мајстора Гавеле, Ступице, Мате Милошевића, Хуга Клајна, Љубише Ристића, читаоцу се сугерише шта је позориште и позоришна режија. Гавели, ствараоцу модерног редитељског позоришта, основним елементима његовог позоришта, стила и поетике посвећен је есеј „Doktor Branko Gavela, redatelj”. Приказујући књигу Николе Батушића Gavela, književnost $i$ kazalište (1983), Јован Христић се, уз савесну научну анализу, усмерио есејистички ка питањима опште природе позоришта, првенствено никад до краја решеном питању позоришне естетике, односа редитеља према драмском тексту, препознајући у Гавели заступника књижевности у позоришту који „nije prezirao pisce i nije ih smatrao budalama koje ne znaju šta su napisale sve dok im neki genijalni reditelj to ne objasni... on je suviše dobro znao kako pozorišna predstava stiče postojanje tek u najdubljem dosluhu sa literaturom" (Христић 2002: 77-78). На специфичан начин обликован је оглед о Јовану Путнику - истовремено и приказ књиге, и портрет редитеља и есеј о необичној личности нашег позоришног живота, потенцирајући основне појмове његове поетике (,динамика артикулисаног простора", редитељска логика") а нарочито његова истраживања о сценском простору. Сличним поступком изграђен је и есеј „Misliti teatrom" у коме говорећи о књизи Iz prakse Георгија Пара, Гавелиног ученика, Христић говори о Паровом идеалу позоришта - позорници и гледалишту као јединственом драмском простору. И есеј „Razgovarati o teatru” може се тумачити као наставак „приче” о односу редитеља према драмском тексту у којој је најузбудљивије место „сеоба душа у театру”, којим се заокружује појам режије Божидара Виолића који сматра да се режија „ne potvrđuje time što reditelj misli protiv i mimo pisca, kako bi nam svima pokazao da i on misli, nego time što reditelj misli zajedno sa piscem” (Христић 2002: 102). Ако бисмо есеј „Jan Kot u pozorištu” изузели из расправе о есејима Јована Христића, не би нам се могло много замерити. По свим својим одликама: радња, карактери, композиција, овај оглед би се могао уврстити у особене Христићеве приче које су на размеђи есеја и приче (таквог су хибридног својства оне прозне творевине у Тераси на два мора). Истовремено, ова прича задржава и све одлике есеја. Описијући како Јан Кот пише, Јован Христић као да описује властити стваралачки поступак: „,...užurbane i katkad zadihane rečenice kojima Jan Kot piše svoje eseje traže od nas da pred sobom vidimo predstave koje još nisu odigrane i da još jednm vidimo one koje su odigrane” (Христић 2002: 117). У есеjy „Bedni Vujiču naš, slatka ti zemlja budi” Христић разбија најтврдокорнију предрасуду о запостављеном позоришном прегаоцу Јоакиму Вујићу о томе да је био „позоришни чергар”: 
представља га онаквог какав је и био - озбиљан позоришни стваралац, човек велике позоришне културе који није заостајао за својим временом. Духовит обрт, особен за стил Јована Христића, да је Милан Предић, један од двојице великих управника Народног позоришта у Београду, ,položio ispit kritičara kao upravnik, a ispit upravnika kao kritičar”, изречен у есеју „Upravnik kao kritičar”, а писан поводом избора позоришних критика Милана Предића Eufrozina ili sudbina glume, одражава суштину пишчеве намере: да представи целовитог позориштника (типичан Стеријин израз на којем Христић инсистира). У овом есеју Христић изриче наизглед успутно и један став који има снагу научног закључка, а односи се на разлику између литерарног и позоришног критичара: „pozorišni kritičar se ne predstavlja antologijskim izborom svojih tekstova; on se pre svega predstavlja svojom vernošću pozorištu, svojim prisustvom i učestvovanjem u životu pozorišta; pozorište se prati, sa njim se živi, u njega se svraća" (Христић 2002: 127). Из овог есеја проговори и личност педагога, његов благи саветодавни карактер, скреће пажњу на образовну вредност Гролових и Предићевих текстова: „nijedan sadašnji, ni budući dramaturg bilo kog našeg pozorišta ne sme a da ih pažljivo ne pročita” (Исто 129).

\section{Есеји о позоришној критици}

„Године учења и године лутања једног позоришног критичара”, тај опсежни, прегледан и систематизовани „дводелни” есеј, намеће се као одличан увод у анализу есејистичких својстава Христићеве позоришне критике. „Kakav je to poziv ići u pozorište?”, пита Христић у овом сублимном огледу исповедног, субјективистичког тона. Сећање обликује његов стил: „sećanje može postojati i bez onih koji se sećaju, da glumci i predstave mogu nastaviti da žive u nekom prostoru koji nije psihološki prostor pamćenja, i time ono pobeđuje svoju kratkotrajnost” (Христић 2002: 10).

Позоришне критике сабране у четири књиге (Позориште, позориште и Позориште, позориште II, Позоришни реферати I и II), збијене и уланчане, са везивним ткивом које чине Христићеве есејистичке нити доимају се као једна жанровски неухватљива, хибридна форма. Могуће их је читати као независне микроцелине, као архивиране позоришне критике, као непрекинуту позоришну хронику, али и као узбудљиву, меланхоличну прозу о позоришном животу и позоришној историји. Могуће им је приступити и као нетипичном универзитетском приручнику за будуће позоришне критичаре. ${ }^{4}$ На научност, театролошку природу књиге упућује и Indeks pozorištnika, како назива Именски регистар и регистар наслова.

Велики ерудита, научник, драмски писац, преводилац и позоришни критичар не прикрива благи презир према научном помодарству очитованом у

\footnotetext{
${ }^{4}$ Павис такође сматра да ,polje rada kazališnog kritičara ne bi trebalo potpuno odvajati od polja rada autora članka objavljenoga u specijaliziranoj publikaciji (časopisu o kazalištu), ili čak autora kakve bolje dokumentirane sveučilišne studije" (2004: 162).
} 
усиљеној и пречесто експлоатисаној научној терминологији, те се, почесто, огласи јетком иронијом и подсмехом:

Nisam pri ruci imao nikakvu enciklopediju najsavremenijih kritičkih pojmova, i zato nisam mogao da ovu beskrajno dugu predstavu što nas je od nekadašnje Bajlonijeve pivare prošetala Skadarlijom da nas vrati u njen podrum, pretvorim u neki kod, označeno i označitelja, globalnu metaforu ili nešto slično (Христић 1982: 224).

Или још директније: Ti beskrajno naduvani signifiants nikako nisu mogli da prikriju siromaštvo svojih signifies, pa su sva jurcanja po pozornici bila smrtonosno dosadna (Христић 1982: 254).

Књиге Христићевих критика организоване су у поглавља насловљена онако како се обележавају позоришне сезоне, сугеришући читаоцу веродостојност, проверљивост чињеница, података. А испод те хладне површине „позоришних хроника”, како сам аутор прикрива природу својих текстова, из којих су нека „suviše literarna razglabanja izostavljena” (Христић 1982: 316), налазе се одељци који већ насловом сугеришу есејистичку природу, уверљиву слику, опис позоришног живота: „Bajka o caru Lenjinu i druge pozorišne priče”, „Stabilizacioni Šesnaesti Bitef”, „Šest premijera bez suvišnih posledica”, итд. Одатле је, запажа Бошко Милин, могуће „видети како се може бити строг али праведан, тачан али без цепидлачења, духовит али не и суров, јасан али не и досадан" (2013: 78).

Вредност Христићевог критичког метода у приступу позоришној представи најбоље би се могла објаснити употребом синтагме „нетеатралност позоришне критике” јер se она „redovno koristi terminima i postupcima književne kritike i uvijek više liči kritici književnoga nego li kritici kazališnog djela" (Kapaхасан 1983: 9). Формална анализа која би дала наслутити „teatralnost predstave”, njezina „,̌isto kazališna svojstva”, сматра Карахасан, „naša kazališna kritika ni u svojim najboljim izdanjima, dakle onda kada je sasvim solidna književna analiza, nije u stanju izvesti naprosto zato što ne zna šta je „kazališna činjeniса" (Исто: 11). Христић је управо аутор који одлично уочава разлику између књижевне и позоришне чињенице.

У Христићевим критикама може се уочити и заметак будућег есеја, као када, рецимо, пише о представи Центрифугални играч Тодора Манојловића (режија Паоло Мађели, Београдско драмско позориште). Уз оцену лепе позоришне вечери „у једном давном свету” не може да „прикрије неке успомене које је ова представа у њима пробудила" (Христић 1982: 67) помињући сусрет са класиком наше модерне поезије који рецитује Дантеа на италијанском. Тај сусрет постао је окосница есеја „Два огледа о стиду” (Христић 2002: 73-83), који налазимо у књизи Тераса на два мора. ${ }^{5}$ Сви Христићеви есеји су испреплетани, прожети анегдотама, присећањима, асоцијације из једног есеја настављају се у другом, допуњавају, објашњавају. Христићеве позоришне

\footnotetext{
5 „Структурни елементи: избор теме, композиција, мотивација и карактеризација, те ограничавање на један структурни елеменат, један лик, један догађај и један начин карактеризације недвосмислено жанровски одређују поједине текстове као причу, а научност, доказана на основу технике закључивања установљена у другим текстовима сврставају их у подручје есеја" (Млађеновић 2003: 430).
} 
критике јесу савесно и продубљено читање одличних и важних представа, и исто тако језгровито, сублимисано, аргументовано збијено, оних које не заслужују детаљнију анализу. Тако се догађало да у десет редова, „сахрани” безнадежно празне представе и писца и редитеља и позориште: „Nema sumnje u jedno: Aleksandar Popović je pisac koji je stekao pravo da napiše i lošu dramu" (Христић 1982: 133). Али зато, рецимо, Балкански шпијун, Хрватски Фауст и неке друге представе бивају опсежно анализиране. „Критеријум дужине” није пресудан за одређивање суштине есејистичког жанра, сматра Женет, јер је централна функција критичког есеја „коментар, или мешавина, у различитим размерама које су руку на срце неодредиве, описивања, тумачења и прећутног вредновања" (Женет 2002: 9).

Христић се непоколебљиво држи става да „нема великог позоришта без велике литературе” (Христић 1973: 65) и на том ставу заснива поетику своје позоришне критике: он је за „позориште које прихвата изазов сјајне литературе”, позориште у коме нема „ни радикалних упута, ни глобалних метафора, ни стања душе који театар наметљивих проблема занемарује” (Христић 1985: 1060). Једноставност и директност су најучесталије квалификације Христићеве позоришне критике.

Ako posle ove večeri Narodno pozorište ne postavi na svoju veliku scenu Operu za tri groša, onda njegova Uprava ne zna šta radi (Христић 1982: 83).

Nastala je neka čorbica koja je uprkos raskošnoj opremi [...] izgledala prilično tanko i jadno. (Исто: 159); izvanredna predstava, ali s fabričkom greškom.

Tako savršena papazjanija da se u njenim mnogobrojnim začinima i prilozima gubi ono malo osnovog ukusa što bi ga mogla imati (Исто: 185).

u mutljagu [...] teksta (Исто: 194).

Otišao sam pre kraja. Bilo je mnogo sasvim mladih ljudi koji su takođe otišli, što će reći da ipak nisam nepopravljivi konzervativac i fosil (Исто: 221).

Понекад обрће у парадокс неку општу мисао, пародирајући цитат или пословицу: „Изашао сам из позоришта и схватио да ништа нисам схватио” (Христић 1990: 710).

Неретко направи духовита поређења: „Zato mi se čini da bi se predstava [...] najbolje mogla opisati kao neka vrsta pozorišne doboš torte: red svetla, red mraka" (Христић 1982: 98).

Антологијска духовитост Јована Христића која се с колена на колено препричава по позоришним бифеима: „Predstava traje dva časa i ima jednu pauzu. Mogućnost koju ona pruža ne treba propustiti. Drugi deo je još gori” (Христић 1982: 115).

Језгровитост, неусиљен тон (,пустимо сад то”) биран и једноставан речник, ненаметљивост у излагању, у доказивању, у дискусији, све су то особености Христићевог есејистичког стила. „И када анализира и када хвали, а нарочито када критикује, Христић никада не склизне у агресивну полемику, у острашћено залагање за оно што сматра да је вредно или тачно" (Фрајнд 2013: 33). 


\section{Закључак}

Христићеви есеји о драми и позоришту имају неколико константи: причу о односу драмског текста и позоришне представе, о позоришној критици и судбини позоришног критичара. На њихов је облик и стил утицало свакако „и Христићево поимање есеја, које ће добити израз у Облищима модерне књижевности, где се есеј схвата као карактеристична форма нашег времена" (Радојчић 2013: 39). Есеј се, упркос бројним есејима о есеју (Адорно, Лукач, Солар) ипак тешко дефинише пре свега због тога што ни његово подручје није најјасније одређено. Све до сада у нашој књижевној критици артикулисане карактеристике стила Христићеве поезије, драмских дела, позоришне и књижевне критике (харомнија између певања и мишљења, идеје и осећања, склад, сразмерност, разложност, строгост) могу се идентификовати и у есејима и представљају неразложиву целину есејистичко-научног мишљења и певања Јована Христића. Парафразирајмо исконског уметника речи: његови су есеји лагана, опуштена шетња кроз драмску књижевност, њену историју и савремено позориште. Ове „полунаучне” расправе које одликују сентенциозност („Bolje imati neki kriterijum, nego se unapred odreći svakog kriterijuma” (Христић 2002: 66)), брза опсервација, медитативност, склоност ка разматрању етичких и филозофских питања, јесу врло често у равни целовитих филозофских расправа.

\section{ИЗВОРИ}

Христић 1982: J. Hristić, Pozorišni referati, Beograd: Nolit.

Христић 2002: J. Hristić, O traganju za pozorištem, Zrenjanin: Gradska narodna biblioteka „Žarko Zrenjanin”.

Христић 1986: J. Hristić, Oblici moderne književnosti, Beograd: Nolit.

Христић 1990: Зима нашег незадовољства, Книжевност, год. 45, књ. 89, св. 4, 719-723.

Христић: 2005: Ј. Христић, Изабрани есеји, Београд: Српски ПЕН центар.

\section{ЦИТИРАНА ЛИТЕРАТУРА}

Женет 2002: Ж. Женет, Фигуре V, Нови Сад: Светови.

Карахасан 1983: Dž. Karahasan, y: Predstava i jezik kritike, Pozorišna predstava i jezik kritike, Novi Sad: Sterijino pozorje.

Мароевић 2016: T. Maroević, S klasicima srođen, s njima ulančan, Sarajevske sveske, br. 37-38. (http://www.sveske.ba/bs/content/s-klasicima-sroden-njima-ulancan 18. 08. 2016). 
Милин 2013: Б. Милин, Бошко, Јован Христић - позоришни критичар и професор позоришне критике, у: Зборник Матице за језик и књижевност, Нови Сад: Матица српска, књ. 61, св. 1.

Млађеновић 2006: M. Mlađenović, Od zvezda do ljudskog tela, Scena, Novi Sad: Sterijino pozorje, br. 2, godina XLII, april-juni, 152-156.

Млађеновић 2003: М. Млађеновић, Модерна медитеранофилија, Летопис Матице српске, Нови Сад: Матица српска, књ. 472, св. 3, 426-430.

Pavis: 2004: P. Pavis, Pojmovnik teatra, Zagreb: Akademija dramske umjetnosti/ Centar za dramsku umjetnost/Izdanja Antibarbarus.

Радојчић 2013: С. Радојчић, Филозофски аспекти Христићеве есејистике, у: Зборник Матице за језик и књижевност, Нови Сад: Матица српска, књ. 61 , св. 1.

Селенић 1981: С. Селенић, Списатељско поштење, Београд: НИН, 15. новембар 1981.

Фрајнд 2013: М. Фрајнд, Јован Христић - драмски писац, критичар, преводилац, уредник - Европљанин, у: Зборник Матице за језик и књижевност, Нови Сад: Матица српска, књ. 61, св. 1.

Milivoje V. Mlađenović

ESSAYS ON DRAMA AND THEATRE BY JOVAN HRISTIĆ

(Summary)

This paper analyses the style of the essays on drama (Kozačinski, Sterija, Trifković, Bojić, Simović etc.) and theatre by Hristic and determines the relation towards the very essence of the dramatic and theatric categories. The author's interventions, comments and reflections which provide the texts with an essayistic structure are identified. Special focus shall be put on humor and irony as a specific feature of Hristić's theatric criticism (Theatrical Reports; Theatre, theatre), the satirical-ironic "criticism of criticism", the ridicule of the "know-it-all" modern critics. The conclusion highlights that the style features of Hristićs poetry, plays, theatrical and literary criticism (balance between singing and thinking, ideas and feelings, harmony, proportionality, reasonableness, rigorousness) are equally present in his essays and that they are an integral part of the essayistic and scientific reasoning of Jovan Hristić. 